\title{
FULL-SCALE TESTING OF REINFORCED CONCRETE FRAME BUILDINGS WITH ATTACHED WALLS CONSIDERING DAMAGE CONTROL DESIGN
}

\author{
Toshikazu Kabeyasawa ${ }^{1}$, Tomohisa Mukai $^{2}$, Hiroshi Fukuyama ${ }^{3}$, \\ Haruhiko Suwada ${ }^{4}$ and Hiroto Kato ${ }^{5}$
}

(Submitted February 2017; Reviewed July 2017; Accepted October 2017)

\begin{abstract}
Static loading tests on two full-scale reinforced concrete buildings were conducted at Building Research Institute in 2014 and 2015 to verify the effectiveness of damage control design utilizing walls. The tested buildings were five-storeys high with two bays in the direction of loading. The 2014 specimen was a moment resisting frame consisting of beams and columns with wing walls. The 2015 specimen contained wing walls, spandrels and hanging walls attached to the columns and beams. The measured strengths were much higher than the calculated strength of the bare frame without these walls. The hysteretic curves showed ductile behaviour in the 2014 specimen until ultimate drift, while strength deterioration was observed in the 2015 specimen. From the cracking pattern and the storey drift distributions within the specimens, the first specimen formed a beam sway mechanism, and the second specimen formed a mixed mechanism with column yielding between the $1^{\text {st }}$ to $3^{\text {rd }}$ storeys. The residual cracks of the specimens were generally wider due to the concentration of the plastic hinge region, although the damage was evaluated as slight at $0.33 \%$ drift and as minor at $0.75 \%$ based on the residual energy capacity. Damage grades evaluated from the residual energy capacity were obviously smaller than the damage grades evaluated from the residual crack widths in accordance with the damage evaluation guidelines.
\end{abstract}

\section{INTRODUCTION}

A number of reinforced concrete buildings suffered damage such as concrete cracking in regions of higher seismic intensity during the 2011 earthquake off the Pacific coast of Tohoku [1]. As mentioned in post-earthquake damage observations, several reinforced concrete buildings designed according to the current Japanese seismic code were not operational shortly after the earthquake, although the damage of the buildings was not as severe as that of a storey collapse or a pancake collapse. The performance requirements of the current Japanese seismic code follow two requirements; 1) the building does not require repair after frequent ground motions, and 2) the building does not collapse and the safety of human lives in extreme ground motions can be confirmed. The code allows the loss of post-earthquake functionality of the building in a large-scale earthquake. However, the seismic performance of buildings required by Japanese society has changed during the experiences of recent severe earthquakes in Japan. In addition to human lives being assured by the code, the building owners hope for post-earthquake functionality after a large-scale earthquake. So far, the importance factor for public buildings, which is originally a safety margin against extreme ground motions, was substituted as the index for the postearthquake functionality [2]. In order to establish a reasonable design requirement for buildings to ensure the post-earthquake functionality with light repair after a large-scale earthquake, it must be refined through post-earthquake damage observations and full-scale testing of buildings.

\section{PROPOSED SEISMIC RANKS}

National Institute for Land and Infrastructure Management and Building Research Institute jointly have been working towards developing new damage control design procedures for reinforced concrete buildings utilizing wing walls, spandrels and hanging walls under the national project "the Development of Function Sustaining Technologies for Buildings used for Disaster Management”. This project proposes a new type of structure which targets post-earthquake functionality achieved by conventional structural design methods and technology without the use of advanced technology such as damper braces or base isolation systems. This damage control design improves the lateral load carrying capacity of moment resisting frames, satisfying the current Japanese seismic code by the use of wing walls, spandrels and hanging walls. These walls are attached to either end of an opening in a moment resisting frame. Wing walls locate on either side of the opening. Spandrels locate on the bottom of the opening. Hanging walls locate on the top of the opening. Mullion walls locate in central part of the opening and it is only connected to the upper and lower floor beams. The requirement of base shear coefficient does not exceed the maximum requirement in conventional Japanese design calculation, so that it does not induce the frequent damage of the foundation. The damage sustained by the building can be limited by reducing the maximum storey drift under largescale ground motions. Those frames have sufficient energy dissipation capacity under either 1.25 or 1.50 times the design earthquake ground motion. The design procedure of the building can be classified into the following two cases according to the assumed damage of the building after a largescale earthquake ground motion.

\footnotetext{
1 Corresponding Author, Associate Professor, Tokyo Metropolitan University, formally with NILIM, Tokyo, Japan, tosikazu@tmu.ac.jp

2 Director, National Institute for Land and Infrastructure Management, Tsukuba, Japan, fukuyama-h92ta@ mlit.go.jp

3 Senior Research Engineer, Building Research Institute, Tsukuba, Japan, t_mukai@kenken.go.jp

4 Senior Researcher, National Institute for Land and Infrastructure Management, Tsukuba, Japan, suwada-h92h9@mlit.go.jp

5 Senior Research Engineer, Building Research Institute, Tsukuba, Japan, pckato@kenken.go.jp
} 
Seismic Rank II: Moment resisting frames consisting of beams and columns with wing walls

The damage control design of frames of seismic rank II possess high strength and stiffness rather than simple moment resisting frames because the columns have attached wing wall sections. The maximum storey drift is reduced under a largescale earthquake, preventing the damage of structural members, non-structural members and disability of the facility equipment. The other panels such as hanging walls, spandrel walls and mullion walls are separated from the main frame by forming gaps from the surrounding beam and columns, reducing the extent of concrete cracking, and allowing for a beam sway mechanism in the structural design. The gaps are normally filled by resin materials and covered in order to prevent rainwater from penetrating inside the building.

This design method can be adopted for middle-high rise reinforced concrete buildings. However, the strength of the frame increases only by the shortening of the clear span length of the beams, such that it is difficult for the frame to remain elastic under a large-scale earthquake ground motion. The design allowed for nonlinear response of structural members to some extent, with the damage of the building remaining minor under a large-scale earthquake ground motion. In this study, the performance of the designed frame was demonstrated in a 2014 full-scale reinforced concrete building.

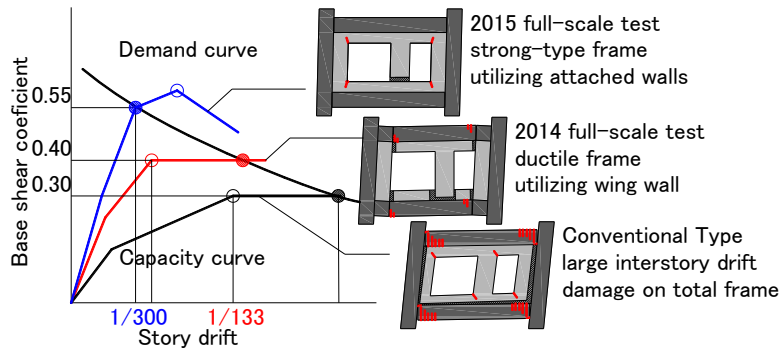

Figure 1: Damage control design concept.

Seismic Rank I: Moment resisting frames consisting of beams with spandrel walls and hanging walls and columns with wing walls

The damage control design of a frame of seismic rank I would require that the frame remains elastic under a large-scale earthquake ground motion and utilizes the attached spandrel walls and hanging walls as well as wing walls. The repair after a large-scale earthquake is almost unnecessary except for those required for the long-term service of the building. The damage of the building remains minor under a large-scale earthquake ground motion.

The ultimate flexural strength of the beams increases due to the attached spandrel and hanging wall sections as do the columns with the attached wing walls, and the lateral load carrying capacity of the frames is much higher than that of the moment resisting frame or the previous wing wall frame. The hysteretic behaviour of the total frame shows the strength deterioration following a large storey drift due to the compression failure at the end of the concrete section of the beams and columns, and as such the ductile performance of the members should be confirmed by providing sufficient wall thickness, reinforcement or the confinement by the transverse reinforcement.

The base shear coefficient of the frame is required to be higher than 0.55 (the maximum value in the Japanese design calculation), so that it is difficult to adapt this design to middle or high rise buildings with this high shear coefficient. Mullion walls usually sustain diagonal shear cracks during small storey drifts, and as such these are separated from the main frame by a horizontal gap. Other walls attached to the moment resisting frame are regarded as structural members, and the location of windows and doors cannot be changed after the design has been completed. Because the aspect ratio of the member section is high, the shear stress in the member section in turn is high in comparison to that of a moment resisting frame subjected to the same storey drift. Careful design is required to ensure a flexural failure of these members. In this study, the performance of the designed frame was demonstrated in a 2015 full-scale reinforced concrete building.

\section{SPECIMEN}

\section{Outline of the Specimen}

To verify the proposed damage control design, a static loading test on a full-scale reinforced concrete building was carried out twice [3]. The plan and elevation views of the test specimen are shown in Figure 2.

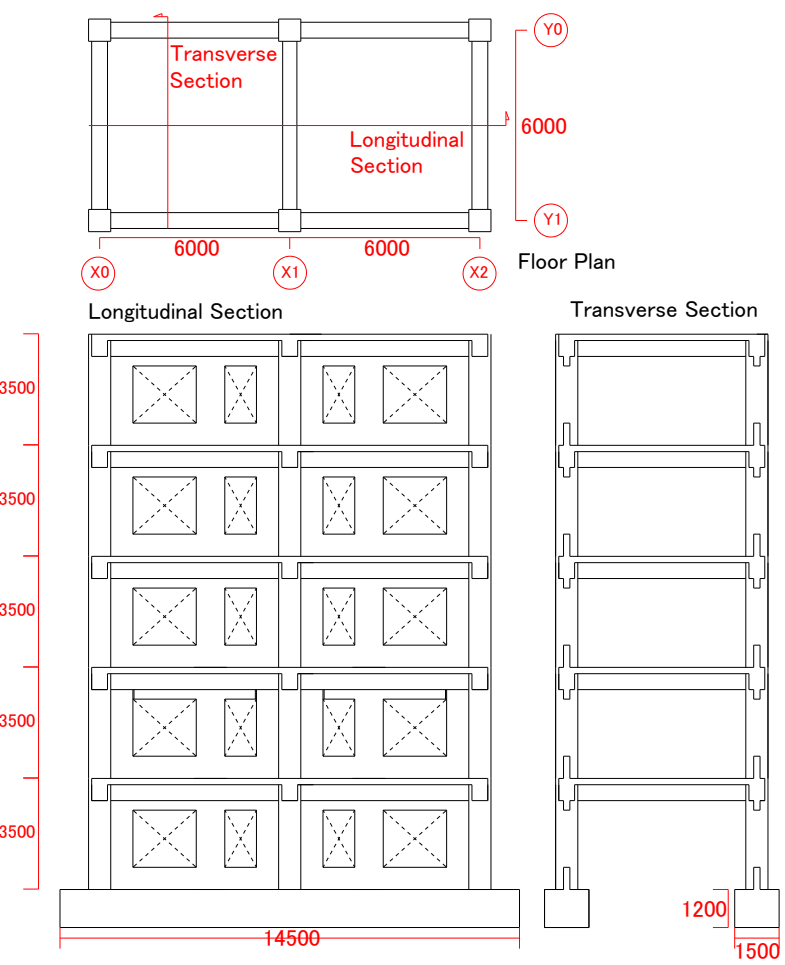

Figure 2: Elevation and section of two full-scale test specimens (unit mm).

The specimen was a full-scale five storey reinforced concrete building with 2 spans and 1 bay. The specimen was built in the laboratory of the Building Research Institute at Tsukuba, Japan. The frame had infilled concrete walls in the longitudinal section. The storey height was $3.5 \mathrm{~m}$ and the total height of the building was $18.7 \mathrm{~m}$. The beams spanned $6 \mathrm{~m}$, both in the longitudinal and transverse directions and the total weight of the super structure was approximately $5400 \mathrm{kN}$. The base foundation of the specimen was fixed to the reaction slab by prestressed concrete steel materials. Two different sized openings $(2.0 \times 1.8 \mathrm{~m}$, and $1.0 \times 1.8 \mathrm{~m})$ were symmetrically provided on the walls in the $\mathrm{Y} 0$ and $\mathrm{Y} 1$ section, giving a perimeter ratio of openings of 0.51 . The walls were divided into wing walls, spandrel walls, and hanging walls by these openings. In this study, the locations of the gaps within the full- scale specimens were designed so as to not reduce the strength and stiffness of the frame (see Figure 3). 


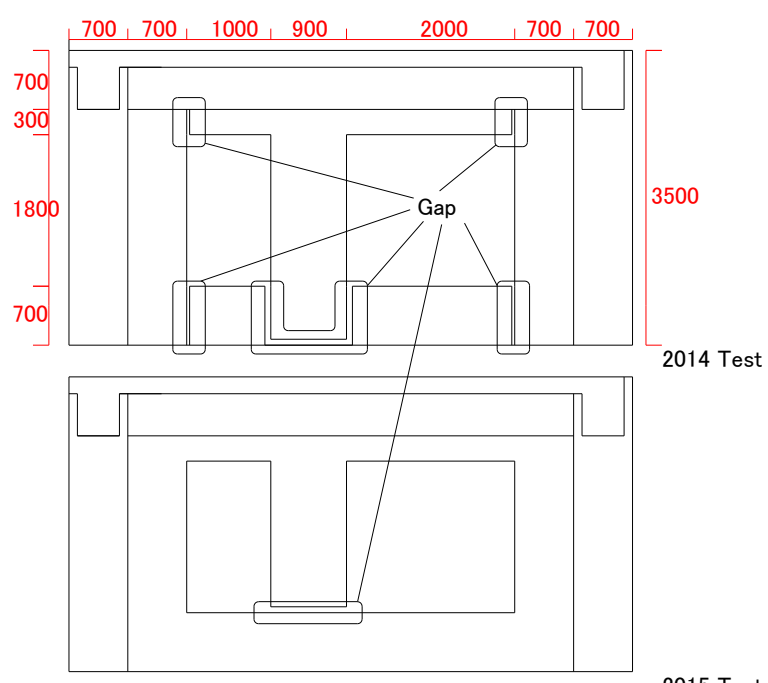

Figure 3: Location of gaps in two full-scale test specimens (unit mm).

\section{Section and Reinforcement of Beams and Columns}

Figure 4 shows sectional views of the beams and columns. Because both the $\mathrm{Y} 0$ and $\mathrm{Y} 1$ frames are outer frames, the storey weight of the specimen per column was smaller than that of a standard multi-bay building. Therefore, the columns were designed under twice the weight of the multi-bay building in the transverse direction.

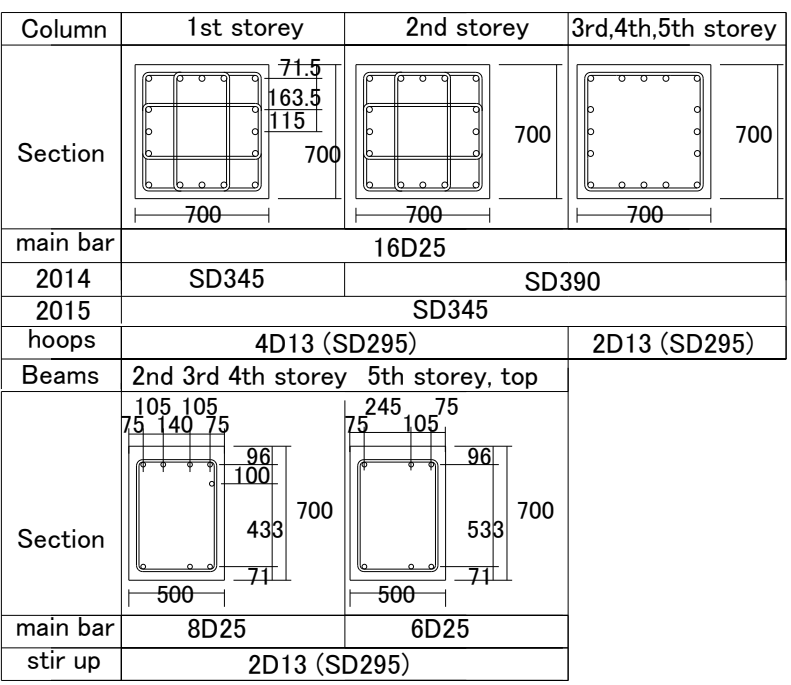

Figure 4: Section list of test specimens (unit mm).

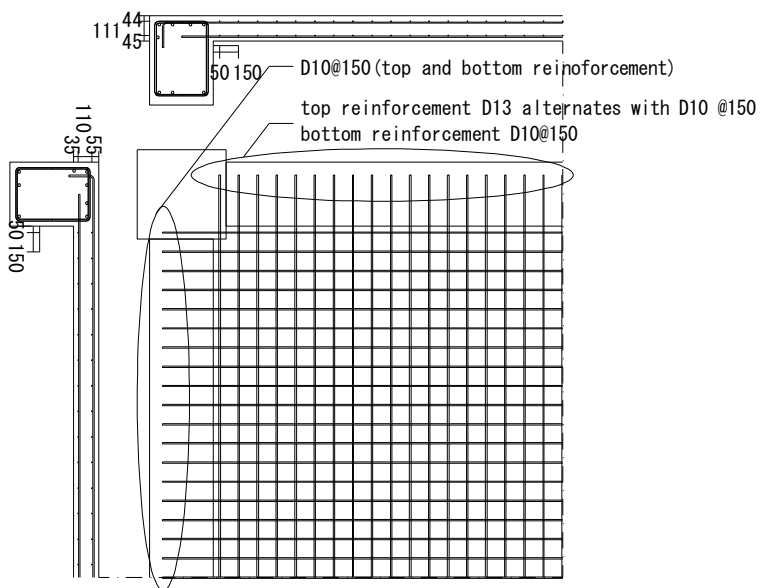

Figure 5: Slab reinforcement of test specimens (unit mm).
The size and reinforcement of the beams and columns were determined by two conditions as well as by conventional structural design [4];1) the maximum storey drift does not exceed $0.5 \%$ under seismic design loading $(\mathrm{C} 0=0.2), 2)$ the base shear coefficient exceeds 0.3 as a lateral load carrying capacity for the plain moment resisting frame without walls. This is because the frame is usually designed as a moment resisting frame by separating the infilled concrete walls from the main frames in conventional design. The columns are700 $\mathrm{mm}$ square sections with sixteen D25 bars $(25 \mathrm{~mm}$ diameter deformed bars) as the longitudinal reinforcing steel. The stirrups consist of four-legged D13 bars at $100 \mathrm{~mm}$ spacings $\left(1^{\text {st }}\right.$ and $2^{\text {nd }}$ storeys) and two-legged D13 bars at $100 \mathrm{~mm}$ spacings (from the $3^{\text {rd }}$ to $5^{\text {th }}$ storeys). The beams are $500 \times 700$ $\mathrm{mm}$ sections with eight D25 bars (from the $2^{\text {nd }}$ to $4^{\text {th }}$ floor), and with six D25 bars ( $5^{\text {th }}$ floor and top beam) as the longitudinal reinforcing steel. Most of the longitudinal reinforcing steel used is grade SD345 (345 MPa nominal yield strength), but grade SD390 was used for the $2^{\text {nd }}$ and $3^{\text {rd }}$ storey columns for the 2014 full-scale specimen alone. Grade SD295 steel was used for bars of diameter smaller than $13 \mathrm{~mm}$.

Table 1: Material testing properties (unit $\mathrm{N} / \mathrm{mm}^{2}$ and $\mathrm{mm}$ ).

\begin{tabular}{|c|c|c|c|c|c|}
\hline \multirow{2}{*}{$\begin{array}{l}\text { Steel rebar } \\
\left(\mathrm{N} / \mathrm{mm}^{2}\right)\end{array}$} & $\begin{array}{l}\text { Wall rebar } \\
\text { Slab rebar }\end{array}$ & Enclosed Hoop & $\begin{array}{l}\text { Longitudinal bar } \\
\text { (columns, beam) }\end{array}$ & $\begin{array}{c}\text { Hoops of column } \\
\text { Stirup of beam }\end{array}$ & $\begin{array}{c}\text { Opening } \\
\text { reinoforcement }\end{array}$ \\
\hline & $\begin{array}{c}\mathrm{D} 10 \\
(\mathrm{SD} 295 \mathrm{~A})\end{array}$ & $\begin{array}{c}\text { D10 } \\
(\mathrm{SD} 295 \mathrm{~A})\end{array}$ & $\begin{array}{c}\mathrm{D} 25 \\
\text { (SD345 or } 390) \\
\end{array}$ & $\begin{array}{c}\mathrm{D} 13 \\
(\mathrm{SD} 295 \mathrm{~A})\end{array}$ & $\begin{array}{c}\mathrm{D} 16 \\
\text { (SD345) }\end{array}$ \\
\hline $\begin{array}{l}\text { Yield strength } \\
2014 \text { test }\end{array}$ & 352 & 372 & $383(449)$ & 340 & 384 \\
\hline $\begin{array}{l}\text { Yield strength } \\
2015 \text { test }\end{array}$ & 349 & 352 & 391 & 331 & 423 \\
\hline \multirow[b]{2}{*}{$\begin{array}{l}\text { Concrete } \\
\left(\mathrm{N} / \mathrm{mm}^{2}\right)\end{array}$} & \multicolumn{5}{|c|}{ Start date of the loading test $(2014 / 12 / 16,2015 / 12 / 03)$} \\
\hline & $\begin{array}{l}\text { 1st storey } \\
\text { 2nd floor }\end{array}$ & $\begin{array}{l}\text { 2nd storey } \\
\text { 3rd floor }\end{array}$ & $\begin{array}{l}\text { 3rd storey } \\
\text { 4th floor }\end{array}$ & $\begin{array}{l}\text { 4th storey } \\
5 \text { th floor }\end{array}$ & $\begin{array}{c}\text { 5th storey } \\
\text { Roof }\end{array}$ \\
\hline $\begin{array}{l}\text { Date of pouring } \\
\text { concrete } 2014\end{array}$ & $2014 / 8 / 21$ & $2014 / 9 / 10$ & $2014 / 9 / 29$ & $2014 / 10 / 17$ & $2014 / 11 / 5$ \\
\hline $\begin{array}{c}\text { Conpressive } \\
\text { strength } 2014\end{array}$ & 34.9 & 33.0 & 37.7 & 33.6 & 31.3 \\
\hline $\begin{array}{l}\text { Young modulus } \\
2014\end{array}$ & $2.86 \times 10^{4}$ & $2.61 \times 10^{4}$ & $2.85 \times 10^{4}$ & $2.62 \times 10^{4}$ & $2.47 \times 10^{4}$ \\
\hline $\begin{array}{l}\text { Date of pouring } \\
\text { concrete } 2015\end{array}$ & $2015 / 8 / 11$ & $2015 / 8 / 29$ & $2015 / 9 / 16$ & $2015 / 10 / 5$ & $2015 / 10 / 22$ \\
\hline $\begin{array}{l}\text { Conpressive } \\
\text { strength } 2015\end{array}$ & 30.2 & 36.8 & 34.5 & 28.5 & 30.2 \\
\hline $\begin{array}{l}\text { Young modulus } \\
2015\end{array}$ & $2.65 \times 10^{4}$ & $2.86 \times 10^{4}$ & $2.72 \times 10^{4}$ & $2.74 \times 10^{4}$ & $2.52 \times 10^{4}$ \\
\hline
\end{tabular}

\section{Section and Reinforcement of Walls}

For the 2014 full-scale test specimen, the gap was provided at the end of the openings in the vertical direction, such that the ductile frame consisted of beams and columns with wing walls. The mullion walls between the two openings were separated by forming gaps along three sides in order to not transfer shear forces into the member. For the 2015 full-scale test specimen, horizontal gaps were provided only between the mullion walls and spandrel walls, and the frames consisted of columns with wing walls and beams with hanging and spandrel walls. The width of the gap was larger than those in standard buildings, in order to prevent the gaps closing during small storey drifts $(45 \mathrm{~mm}$ for corners of wing walls, and $80 \mathrm{~mm}$ for corners of mullion walls).

For the adobe design concept, sufficient reinforcement was positioned in the attached wall sections to account for the high shear or axial stress within the section. Figure 6 and 7 show the section list and reinforcement detailing of the attached wall sections respectively. For the wing wall section, the ratio of the wall thickness to the member depth was high and the bar arrangement was double layered in order to prevent a compression failure at the end of the concrete section during small storey drifts. The end of the wing wall section is specially reinforced with several D16 longitudinal bars and confined by hoops to prevent the buckling of the longitudinal bars. Each hoop is enclosed by gas pressure welding. The longitudinal reinforcement of the wing walls consisted of a 
double layer of D10 bars at $200 \mathrm{~mm}$ spacings, and confined by D10 fixing reinforcement. The transverse reinforcement of the wing walls was anchored in the centre of the columns, and by a 180-degree hook in the end of the wall. The transverse reinforcement of the walls consisted of a double layer of D10 bars at $100 \mathrm{~mm}$ spacings for the $1^{\text {st }}$ storey columns in the 2014 full-scale test, and from the $1^{\text {st }}$ storey to the $3^{\text {rd }}$ storey columns and beams in the 2015 full-scale test in order to ensure the residual crack width was small and prevent the buckling of the longitudinal reinforcement. This transverse reinforcement of beams does not extend to the beam-wall joint zone, because it gives priority to the reinforcement of columns in the joint zone. Other transverse reinforcement was spaced at $200 \mathrm{~mm}$ as along with the standard wall reinforcement. The length of the wing walls was $700 \mathrm{~mm}$ and the heights of the spandrels and hanging walls was $700 \mathrm{~mm}$ and $300 \mathrm{~mm}$ respectively. The opening reinforcement of the spandrels or hanging walls was bent between the double layers of transverse reinforcement The design calculations confirmed that a flexural failure precedes shear failure for the columns and beams with attached walls.

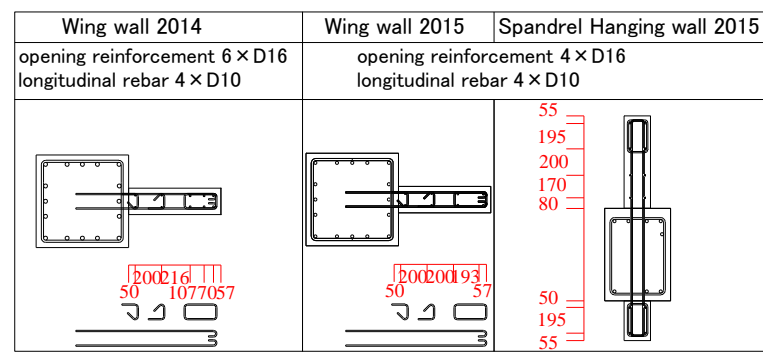

Figure 6: Section list of the attached wall sections (unit mm).

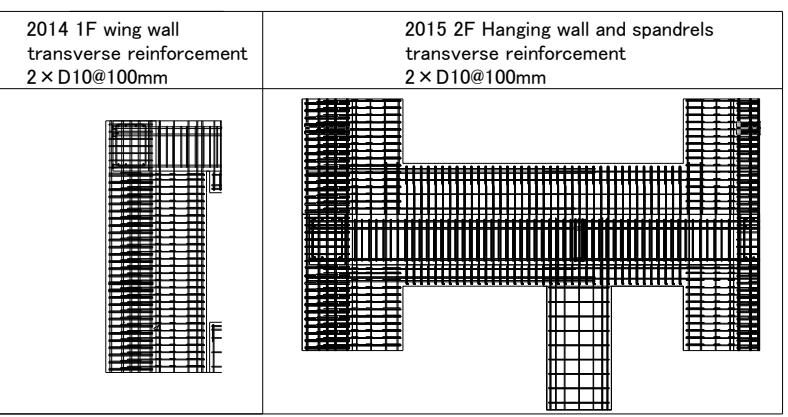

Figure 7: Reinforcement detailing of the attached wall sections.

\section{Loading Setup}

Figure 8 shows the top floor of the full-scale test specimens as an example of the attachment of the actuators. The actuators applied lateral force in $4^{\text {th }}$ floor and top floor. When the actuators are distributed in every floor, the loading capacity decreases and it affected the design base shear or member sections of the test specimen. The number of the actuators used was four on the top floor during both tests along with four on the fourth floor during the 2014 full-scale test and six on the fourth floor during the 2015 full-scale test, taking into account the number available and the loading capacity of the actuators. Those actuators applied lateral force through two concrete blocks positioned both above and below the transverse beams in the $\mathrm{X} 1$ frame, loaded the centre of the floor slab from upper and lower level. The other ends of the actuators were connected to a large reaction wall. The moment centre height of the lateral load was equalized with the centre of the floor slab so as not to rotate the floor slab. It is difficult to simulate the inertia force of the dynamic response completely in a static loading test, but the actuators were anchored in the centre of the floor slab so as not to concentrate the elongation of the beams on one side, as recommended by a past static loading test of a full-scale building [5]. The maximum capacity of one actuator is $\pm 1000 \mathrm{kN}$ within \pm 500 mm displacement.

The two actuators on the top of the specimen were controlled individually by the displacement of the specimen. The other actuators followed the load of those two actuators. The displacement of the specimen was defined as the lateral displacement at the roof level of the reaction wall measured by a magnetic scale. The simplified inverse triangular load pattern was used in the test for the number of the available actuators. The total lateral load applied to the $4^{\text {th }}$ floor level was twice that of the roof level, where the ratio of the overturning moment to the base shear was identical to that under the inverted triangle seismic force. The total drift (the ratio of displacement on the roof level to the total building height) was controlled during the cyclic loading test.

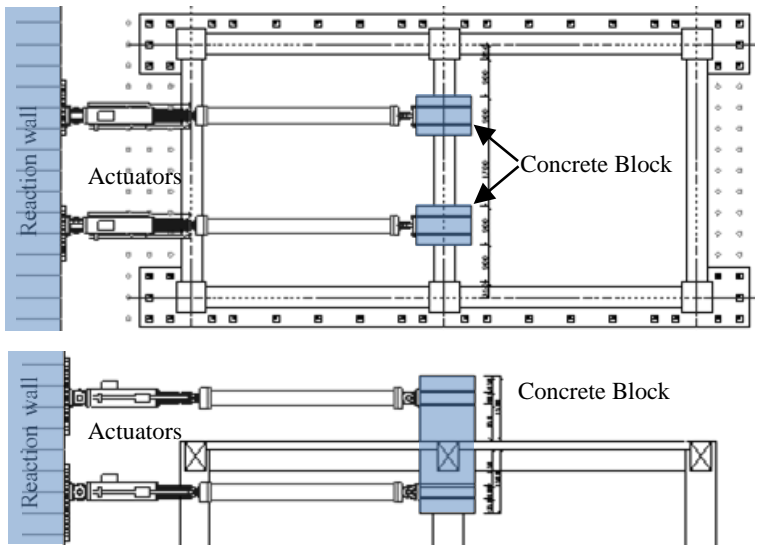

Figure 8: Loading set up in top floor.

\section{RESULT OF THE FULL SCALE TEST}

\section{Load Displacement Relation}

Figure 9 shows the load displacement relationship between total drift and base shear for the 2014 full-scale test. The columns with wing walls normally show strength deterioration after a compression failure at the end of the concrete section. However, this frame showed ductile behaviour until loading to the ultimate state as a result of the dominant contribution of the beams. The strength and stiffness increased locally due to the contact of the mullion walls and spandrels after $1.5 \%$ drift. The inverted S-shape slip behaviour appeared in the $2^{\text {nd }}$ cycle of loading. The collapsing load due to a beam sway mechanism based on the flexural moment strength of each member was calculated to be $4654 \mathrm{kN}$, which is consistent with the maximum load sustained $(4489 \mathrm{kN})$ before the contact with the walls. This maximum base shear of the test specimen is 1.8 times of the maximum strength of bare moment resisting frame in design calculation $(2504 \mathrm{kN})$.

Figure 10 shows the load displacement relationship between total drift and base shear in the 2015 full-scale test. The hysteresis shows elastic behaviour up to $0.125 \%$ drift, and the increase of the restoring force after $1.0 \%$ drift is small because the stiffness had degraded due to the cracking of the concrete or yielding of the reinforcement. The maximum strength was $8261 \mathrm{kN}$, recorded at $0.757 \%$ drift. This maximum base shear of the test specimen is 3.3 times of the maximum strength of bare moment resisting frame in design calculation $(2504 \mathrm{kN})$. The restoring force had been reduced to $95 \%$ of the maximum strength at $1.0 \%$ drift, $80 \%$ of the maximum strength in the $1^{\text {st }}$ loading cycle to $2.0 \%$ drift, and $60 \%$ of the maximum strength in the $2^{\text {nd }}$ loading cycle to $2.0 \%$ drift. The maximum strength 
of this specimen was 1.84 times of the maximum strength of the 2014 full-scale test specimen. Obvious strength deterioration was observed in the 2015 full-scale test. The gaps between the spandrels and the mullion walls were not closed during the test. This discrepancy of load displacement relations in between 2014 full-scale test and 2015 full-scale test is appeared due to the number of the plastic hinges for concrete compression failure in wall sections attached to columns or beams.

The column and beams of the test specimen were designed such that the maximum storey drift would be smaller than $0.5 \%$ under a storey shear coefficient of 0.20 , where twice the weight of the specimen was assumed for the calculation of the shear coefficient. The base shear coefficient of the 2014 fullscale specimen was 0.42 at $0.75 \%$ storey drift, and 0.66 at $0.33 \%$ storey drift assuming twice the weight as discussed above. The stiffness and strength of the frame improved from that of a simple moment resisting frame due to the attachment of the walls. The test specimens obtained sufficient base shear.

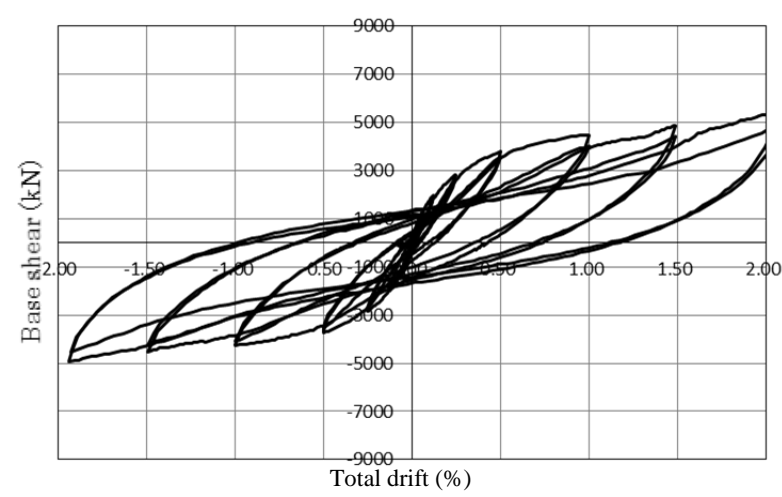

Figure 9: Load displacement relationship (2014 test).

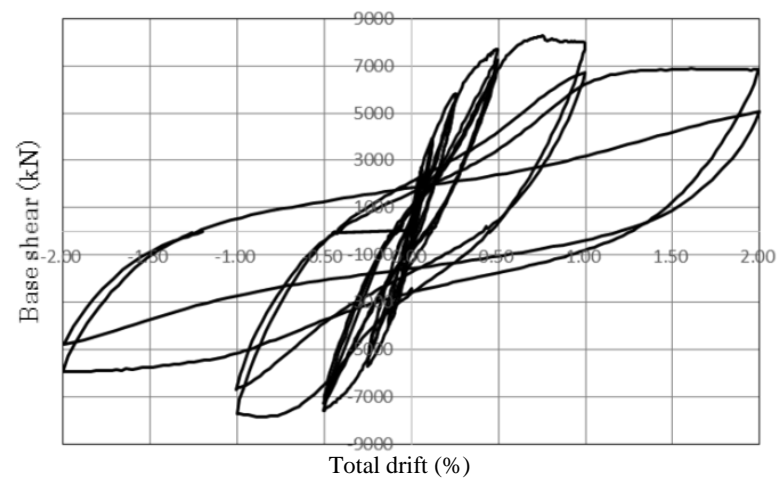

Figure 10: Load displacement relationship (2015 test).

Figures 11 and 12 show the distribution of the storey drifts at the cyclic loading peaks. The maximum storey drift was obtained at the $3^{\text {rd }}$ storey during the 2014 full-scale test. The drifts sustained at the $2^{\text {nd }}$ and $3^{\text {rd }}$ stories were larger than the total drift sustained, and the member damage was concentrated on those stories, while the drift sustained at the $4^{\text {th }}$ and $5^{\text {th }}$ stories was significantly smaller than the other stories.

The recorded storey drifts show a linear distribution up to $0.25 \%$ drift for the 2015 full-scale test, but the storey drifts recorded for the $1^{\text {st }}, 2^{\text {nd }}$ and $3^{\text {rd }}$ stories are prominent in the loading cycles to $0.50 \%$ or larger, as well as for the 2014 fullscale test. The storey drifts are $0.89 \%$ for the $1^{\text {st }}$ storey, $0.93 \%$ for the $2^{\text {nd }}$ storey, $1.01 \%$ for the $3^{\text {rd }}$ storey, $0.47 \%$ for the $4^{\text {th }}$ storey, $0.38 \%$ for the $5^{\text {th }}$ storey when the maximum strength of the test specimen was recorded. Because these specimens show the beam hinging mechanism, the maximum storey drift was obtained in a middle storey of the specimens.

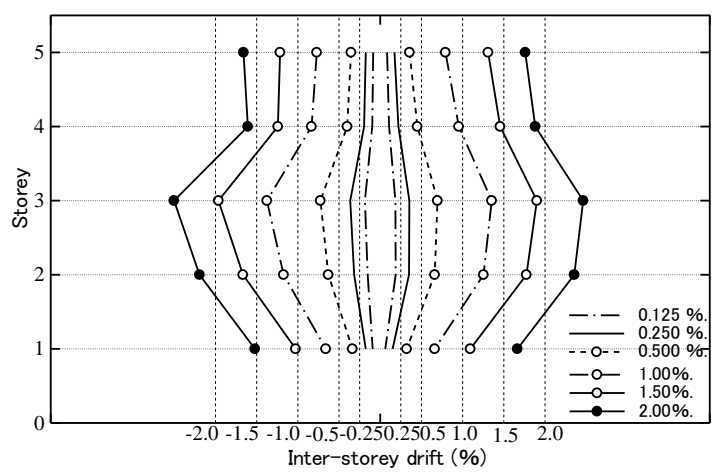

Figure 11: Inter-storey drift distribution (2014 test).

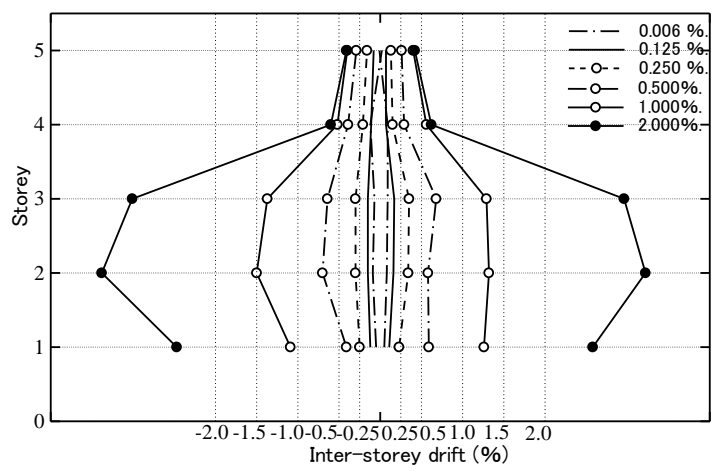

Figure 12: Inter-storey drift distribution (2015 test).

\section{Equivalent Damping Factor}

Figure 13 shows the equivalent damping factor in each loading cycle. The damping factor was evaluated as a ratio of the hysteretic energy dissipation to the maximum elastic strain energy in the $2^{\text {nd }}$ loading cycle, reduced to 0.8 times this value to consider the unstable hysteretic response in an earthquake. The displacement and load of the cyclic loading peak was evaluated in the positive (tensile) loading direction. The damping factor of both specimens exceeded $10 \%$ at the $1.0 \%$ drift loading cycle, and effects of the beam sway mechanism such as slip behaviour in the hysteretic shapes was minor during the test. The damping factor was relatively large in the 2015 full-scale test because the yield drift was smaller due to the effect of the walls attached to the beams. These values exceeded the equivalent viscous damping factor of reinforced concrete frames assumed in Japanese capacity spectrum design calculation [7].

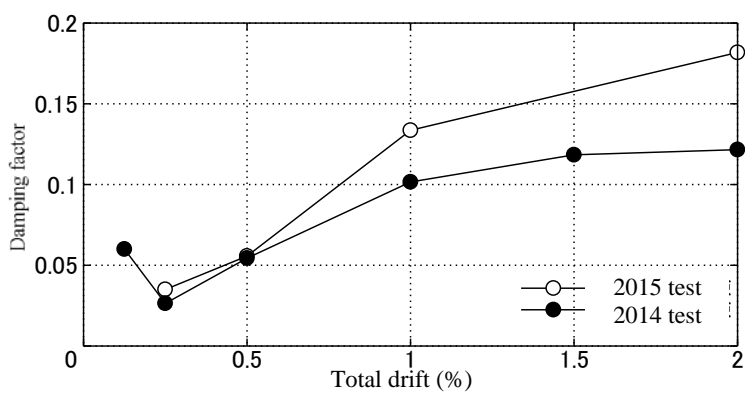

Figure 13: Equivalent viscous damping factor.

\section{Damage Pattern}

Figure 14(a) shows the cracking patterns of the 2014 full-scale test specimen after loading to $0.5 \%$ drift. Flexural cracks on the beams were observed around the gap, and did not develop to the beam column joint. This gap helps enable the frame to form the beam sway mechanism. These cracks were not observed in the other part of the beams due to the attached spandrels, hanging walls and mullion walls. The cracks on the 
floor slab formed parallel to the transverse beams. The cracks on the columns with wing walls were concentrated at the bottom of the columns in the $1^{\text {st }}$ and $2^{\text {nd }}$ stories, indicating that the inflection points of these members were relatively high due to the attached wing walls. On the other hand, the cracks were observed at the top of the columns in the $3^{\text {rd }}, 4^{\text {th }}$ and $5^{\text {th }}$ stories, indicating that the inflection points were low. The gap width around mullion walls was designed such that they would not conflict with the spandrels until loading to $3.0 \%$ storey drift, however these did conflict at $1.5 \%$ drift due to the flexural deformation of the beams.

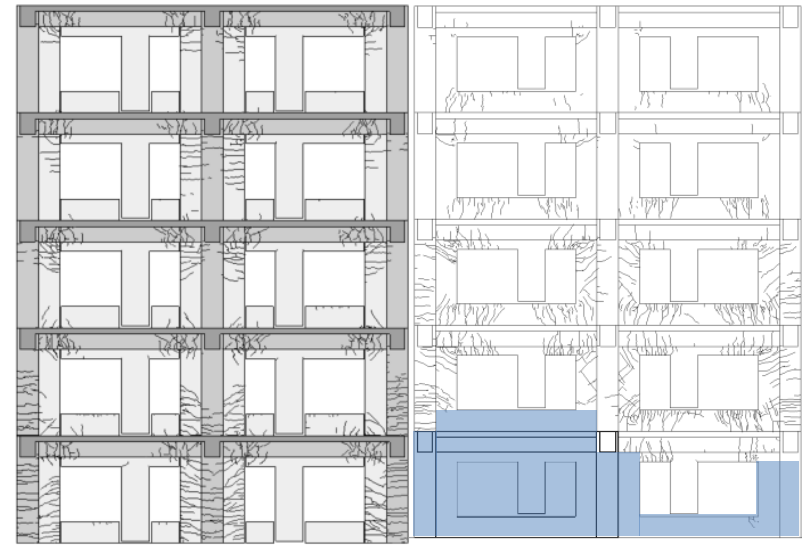

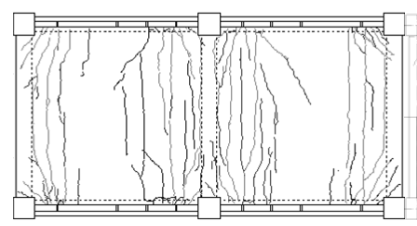

(a) $0.50 \%$ drift (2014 test)

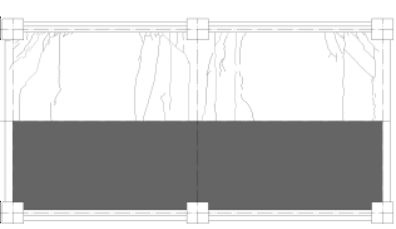

(b) $0.25 \%$ drift (2015 test)
Figure 14: Damage pattern of test specimens.

Figure 15(a) shows the location of yielding of the rebar in the 2014 full-scale test after loading to $1.00 \%$ drift, where $\bigcirc$ indicates longitudinal reinforcement in the wing walls, $\square$ indicates longitudinal reinforcement in the columns, () indicates longitudinal reinforcement in the beams, and indicates slab reinforcement. All of the longitudinal reinforcement in the wing walls in the $1^{\text {st }}$ storey had yielded at $0.25 \%$ drift. The tensile reinforcement in the beams in the $2^{\text {nd }}$, $3^{\text {rd }}$, and $4^{\text {th }}$ storey, the slab reinforcement in the $2^{\text {nd }}$ and $3^{\text {rd }}$ storey, and the tensile reinforcement of columns had yielded at $1.0 \%$ drift.

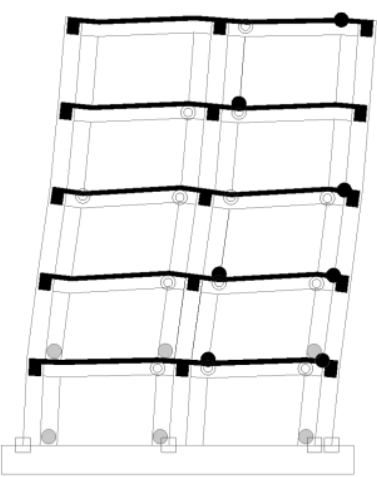

(a) $1.0 \%$ drift (2014 test)

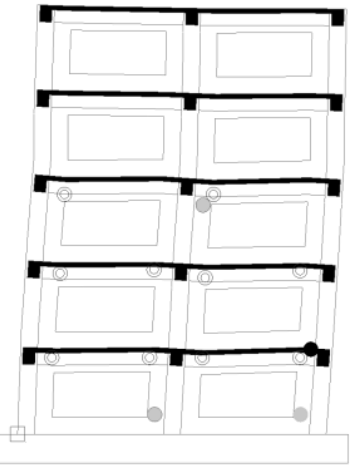

(b) $0.50 \%$ drift (2015 test)
Figure 15: Position of rebar yielding.
Figure 14 (b) shows the cracking patterns of the 2015 fullscale test specimen after loading to $0.25 \%$ drift. In the tinted area, a detailed relationship between total crack length and repair cost has been investigated, and the results of the cracking data will be reported in a further study. Diagonal cracks were observed in the cross section between the spandrels and the wing walls due to the flexural deformation of the beams and columns. The width of the cracks on the wing walls and spandrels in the outer frame was especially large at small drift levels, causing flexural cracks to be developed on the beams and columns. The shear cracks had been observed in the columns with wing walls in the $2^{\text {nd }}$ and $3^{\text {rd }}$ stories at $1 \%$ drift. The cracks were concentrated on the members in the $1^{\text {st }}, 2^{\text {nd }}$ and $3^{\text {rd }}$ storeys, while the cracks on the members in the $4^{\text {th }}$ and $5^{\text {th }}$ storeys were relatively minor.

Figure 15(b) shows the location of yielding of the rebar after loading to $0.50 \%$ drift in the 2015 full-scale test. The longitudinal reinforcement at the bottom of the $1^{\text {st }}$ storey column yielded at $0.25 \%$ drift, and that of the beam yielded at $0.50 \%$ drift. The longitudinal reinforcement at the top of the $3^{\text {rd }}$ storey column yielded at $1.00 \%$ drift, while no reinforcement yielded in the members of the $4^{\text {th }}$ and $5^{\text {th }}$ storey. This indicates that the test specimen had showed a mixed mechanism with column yielding in the bottom three storeys.

Table 2 shows the maximum residual crack width after unloading from $0.25 \%, 0.50 \%$, and $1.00 \%$ drift during the 2014 full-scale test. The residual crack width was large in the beams but not for the columns of the $\mathrm{X} 1$ frame in the $1^{\text {st }}$ storey.

Table 2: Residual crack width (2014 test).

\begin{tabular}{|c|c|c|c|c|c|c|}
\hline & \multicolumn{2}{|c|}{ Total Drift 0.25\% } & \multicolumn{2}{c|}{ Total Drift 0.50\% } & \multicolumn{2}{|c|}{ Total Drift 1.00\% } \\
\hline & Inner End & Outer End & Inner End & Outer End & Inner End & Outer End \\
\hline RF Beam & 0.05 & 0.10 & 0.10 & 0.15 & 1.60 & 1.00 \\
\hline 5F Beam & 0.05 & 0.10 & 0.15 & 0.15 & 3.50 & 3.00 \\
\hline 4F Beam & 0.15 & 0.10 & 1.20 & 1.80 & 3.50 & 5.00 \\
\hline 3F Beam & 0.20 & 0.30 & 1.00 & 2.50 & 3.00 & 5.00 \\
\hline 2F Beam & 0.20 & 0.20 & 1.20 & 1.50 & 1.70 & 5.00 \\
\hline & Column & Attached wall & Column & Attached wall & Column & Attached wall \\
\hline $\begin{array}{c}\text { 1st storey } \\
\text { entre } \\
\text { Column }\end{array}$ & 0.15 & 0.20 & 0.25 & 0.60 & 1.20 & 1.50 \\
\hline
\end{tabular}

In the 2001 Japanese standard for post-earthquake damage evaluation of reinforced concrete buildings [7], a damage grade of flexural beam and columns is defined based on the residual crack width. The damage grade increases when the residual crack width exceeds $0.2 \mathrm{~mm}, 1.0 \mathrm{~mm}$ or $2.0 \mathrm{~mm}$. According to the damage grades of each member, it evaluates a damage of the storey. In this test, the damage was minor for the $1^{\text {st }}, 2^{\text {nd }}$ and $3^{\text {rd }}$ storeys at $0.25 \%$ drift, moderate for the $1^{\text {st }}$, $2^{\text {nd }}$ and $3^{\text {rd }}$ storeys at $0.50 \%$ drift, and severe for the $1^{\text {st }}, 2^{\text {nd }}, 3^{\text {rd }}$ and $4^{\text {th }}$ storeys at $1.00 \%$ drift in the 2014 full-scale test (see Table 4).

Table 3 shows the maximum residual crack width after unloading from $0.125 \%, 0.25 \%$, and $0.50 \%$ drift during the 2015 full-scale test. The crack width of beams in the table indicates the maximum residual crack width in integrated beam section with spandrels and hanging walls. The residual crack width was large in the attached spandrels and hanging walls but not in the columns and beams. The damage was minor for the $1^{\text {st }}$ storey at $0.125 \%$ drift, moderate for the $1^{\text {st }}$ and $2^{\text {nd }}$ storeys at $0.25 \%$ drift, and severe for the $1^{\text {st }}, 2^{\text {nd }}$ and $3^{\text {rd }}$ storeys at $1.00 \%$ drift for the 2015 full-scale test (see Table 4).

However, the restoring force of the total frame increased in proportion to the total drift up to $1.0 \%$ drift in the 2014 fullscale test and $0.50 \%$ drift in the 2015 full-scale test as shown in Figure 9 and 10 respectively, and as such these damage states do not agree with the definition of moderate or severe in Japanese standard for post-earthquake damage evaluation. The rotation of the column and beam hinges are actually larger 
than the storey drift due to the large rigid zone of attached walls in these specimens rather than that of a simple moment resisting frame at an identical storey drift level, but the crack width of those beams was wider than that of the columns due to either the elongation of the beams or the concentration of damage within the hinges due to the attachment of spandrels and hanging walls as shown in Figure 16 and 17. The residual crack width does not convey the damage defined by the residual energy capacity for these particular types of frames.

Table 3: Residual crack width (2015 test) (unit mm).

\begin{tabular}{|c|c|c|c|c|c|c|}
\hline & \multicolumn{2}{|c|}{ Total Drift 0.125\% } & \multicolumn{2}{c|}{ Total Drift 0.25\% } & \multicolumn{2}{c|}{ Total Drift 0.50\% } \\
\hline & Inner End & Outer End & Inner End & Outer End & Inner End & Outer End \\
\hline RF Beam & 0.00 & 0.00 & 0.00 & 0.05 & & \\
\hline 5F Beam & 0.00 & 0.00 & 0.00 & 0.10 & 0.00 & 0.20 \\
\hline 4F Beam & 0.00 & 0.10 & 0.00 & 0.50 & 0.10 & 1.50 \\
\hline 3F Beam & 0.05 & 0.05 & 0.05 & 0.05 & 1.20 & 1.35 \\
\hline 2F Beam & 0.00 & 0.00 & 0.00 & 0.00 & 0.05 & 0.65 \\
\hline & Column & Attached wall & Column & Attached wall & Column & Attached wall \\
\hline $\begin{array}{c}\text { 1st storey } \\
\text { Centre } \\
\text { Column }\end{array}$ & 0.10 & 0.55 & 0.15 & 0.60 & 0.50 & 1.10 \\
\hline
\end{tabular}

Table 4: Damage rate of test specimens (unit mm).

\begin{tabular}{|c|c|c|c|c|c|c|c|}
\hline $\begin{array}{c}\text { Full-scale } \\
\text { test }\end{array}$ & $\begin{array}{c}\text { Total } \\
\text { drift }\end{array}$ & $\begin{array}{c}\text { Max. } \\
\text { storey drift }\end{array}$ & 1st storey & 2nd storey & 3rd storey & 4th storey & 5th storey \\
\hline 2014 & $0.50 \%$ & $0.70 \%$ & Moderate & Moderate & Moderate & Light & Light \\
\hline 2015 & $0.25 \%$ & $0.33 \%$ & Moderate & Moderate & Moderate & Light & Light \\
\hline
\end{tabular}

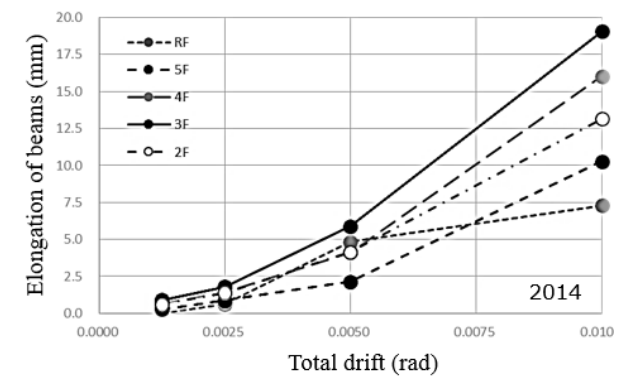

Figure 16: Elongation of beams in the 2014 full-scale test.

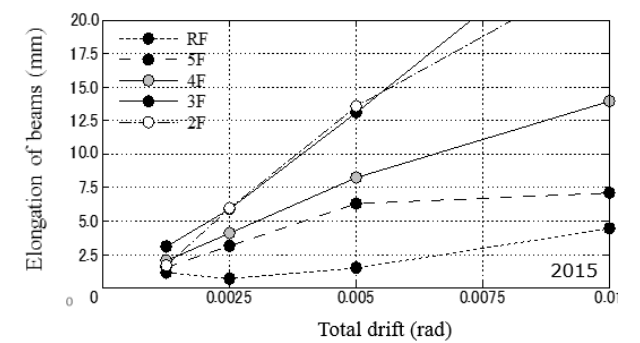

Figure 17: Elongation of beams in the 2015 full-scale test.

\section{Evaluation of Residual Energy Capacity}

The damage of the test specimens was evaluated directly from the load-displacement relationship in this study. The damage of the building was determined by the residual seismic performance factor $\mathrm{R}$, which is the sum of the seismic performance reduction factors, $\eta$, of composing members. Index $\eta$ is the ratio of residual energy capacity Er to the energy capacity at the ultimate state $(\mathrm{Ed}+\mathrm{Er})$ in the loaddisplacement relationship. In post-earthquake damage observations, the seismic performance reduction factor $\mathrm{R}$ of investigated members is evaluated indirectly by the residual crack width (see in Figure 18).

Figure 19 and 20 show the backbone curve and cyclic loading loop of the load displacement relationship for the most deformed storey in each test. In the Japanese capacity spectrum design method, the safe drift limit is constrained to account for the ultimate drift limit of the members. In this study, the ultimate storey drift is equates to a safe drift limit of $1.33 \%$. The backbone curve of the maximum deformed storey is plotted until the maximum storey drift reaches $1.33 \%$ in this figure. The damage of the 2014 full-scale test specimen evaluated from the hysteretic energy dissipation is minor $(\mathrm{R}>80 \%)$ in the loading cycle to $0.50 \%$ total drift (the maximum storey drift is $0.70 \%$ in the $3^{\text {rd }}$ storey), while the damage evaluated from the residual crack width is moderate.

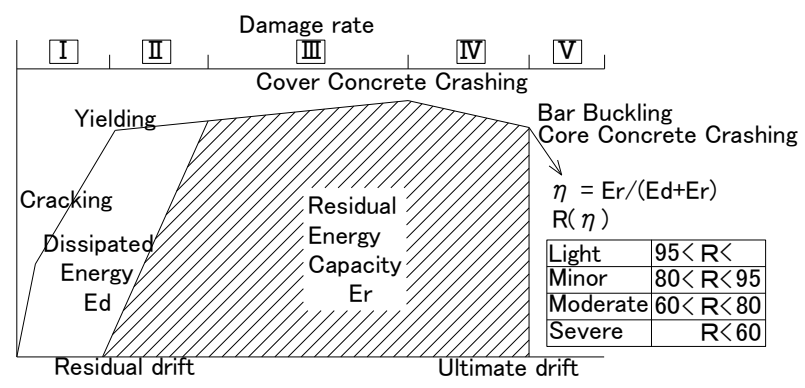

Figure 18: Definition of the Damage rate in 2001 Japanese standard for post-earthquake damage evaluation.

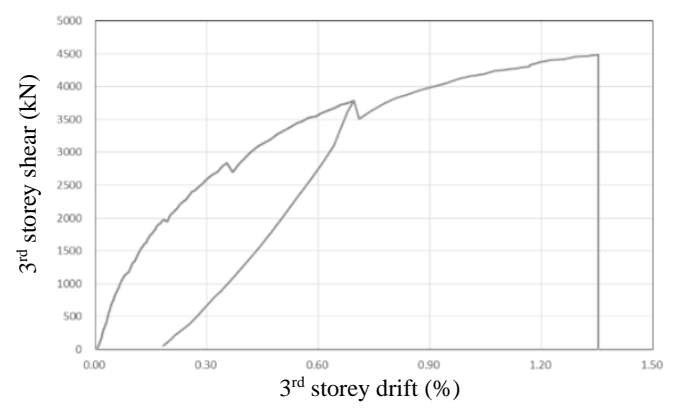

Figure 19: Residual energy capacity of the 2014 full-scale test specimen at $0.50 \%$ total drift loading cycle.

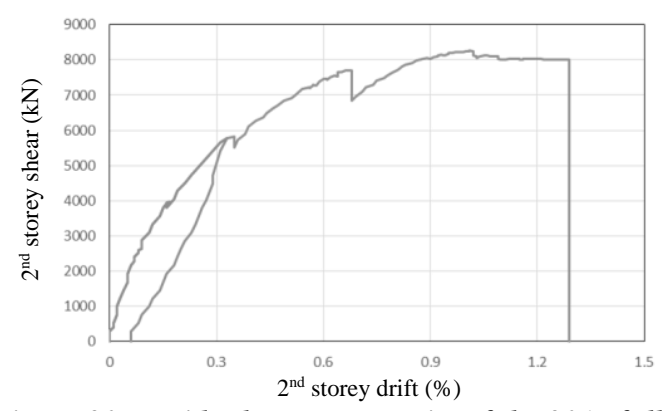

Figure 20: Residual energy capacity of the 2015 full-scale test specimen at $0.25 \%$ total drift loading cycle.

The damage of the 2015 full-scale test specimen evaluated from the hysteretic energy dissipation is light $(\mathrm{R}>95 \%)$ in the loading cycle to $0.25 \%$ total drift (the maximum storey drift is $0.33 \%$ in the $2^{\text {nd }}$ storey), while the damage evaluated from the residual crack width is minor. As the damage can be evaluated directly from the residual energy capacity of the maximum deformed storey, the proposed design controls the damage of the frame under a large-scale ground motion as opposed to conventionally designed reinforced concrete frames, and confirms the functionality of the building after a large-scale ground motion. However, this proposed design focused only on the control of drift limits together with controls on cracking and yielding in the frame and so damage due to the floor acceleration was not considered. Damage to acceleration critical components should also be considered when evaluating the overall outcome of damage control design. The residual crack width of members was wider than $0.30 \mathrm{~mm}$ and light repair would be required for long-term service of the building after an earthquake. 


\section{Curvature of $\mathbf{1}^{\text {st }}$ Storey Columns}

Figure 21 and 22 shows the Curvature distribution of the $1^{\text {st }}$ storey columns. The curvature at around $1000 \mathrm{~mm}$ height is the maximum value for the columns of the $\mathrm{X} 1$ and $\mathrm{X} 2$ frames (wall tensile direction) during the 2014 full-scale test. This height is consistent with the lap splice $(720 \mathrm{~mm}$ height) of the longitudinal reinforcement in the wing wall section. The large flexural crack was also observed at the same height during the test. The inflection points of those three columns were at a height of $2700 \mathrm{~mm}$, and did not change due to the length of the attached wing walls. The inflection points of the $1^{\text {st }}$ storey columns in the 2015 full-scale test were comparatively lower than that of the 2014 full-scale specimen because the clear span length of the members was relatively small due to the attached hanging walls and spandrels, and the average height was about $2000 \mathrm{~mm}$, almost the mid-height of the columns with wing walls.

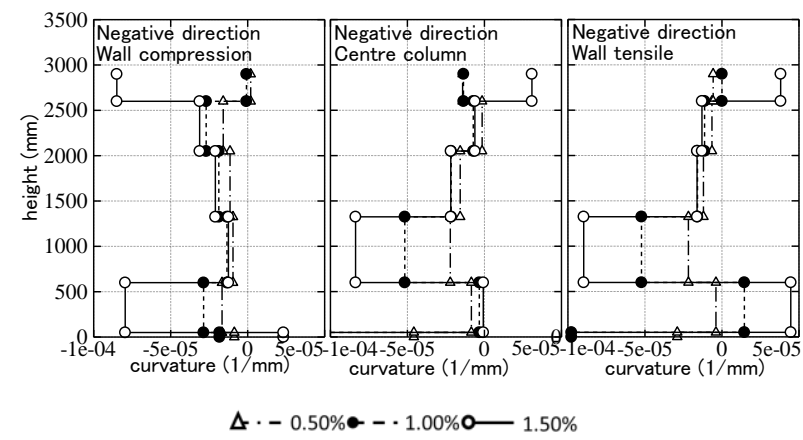

Figure 21: Curvature distribution of the $1^{\text {st }}$ storey columns in the 2014 full-scale test.

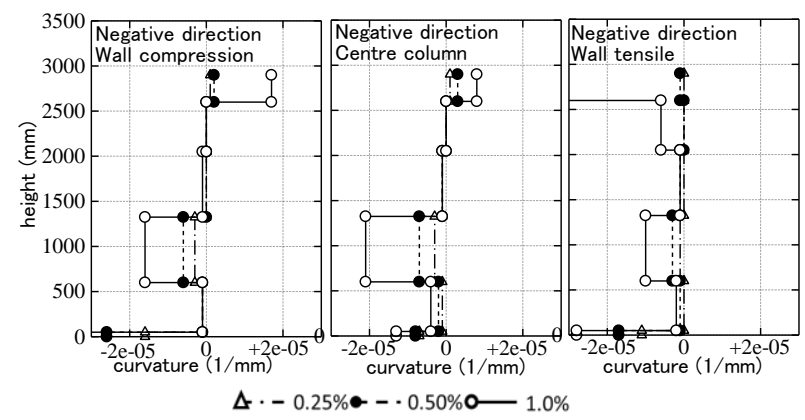

Figure 22: Curvature distribution of the $1^{\text {st }}$ storey columns in the 2015 full-scale test.

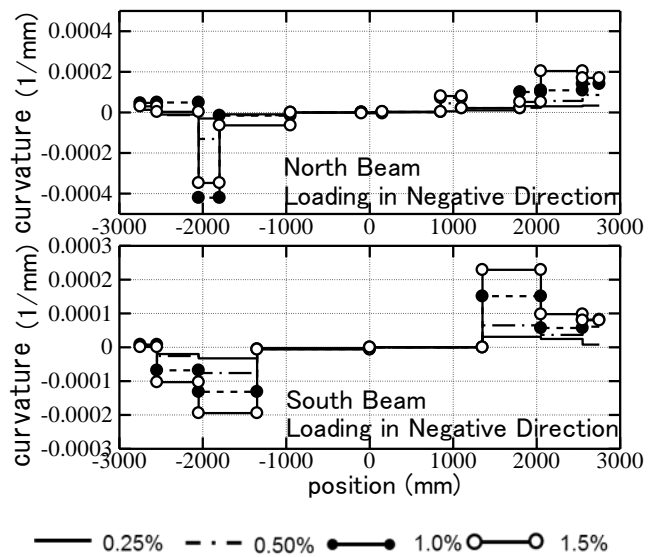

Figure 23: Curvature distribution of the 2nd floor beams in the 2014 full-scale test.

\section{Curvature of $2^{\text {nd }}$ Floor Beams}

Figure 23 and 24 shows the curvature of the north and south beams in the $2^{\text {nd }}$ storey. The average curvature was derived from the difference between the axial deformations measured at the top and bottom of the beams. A large curvature was obtained at the end of the wing wall section, and the plastic hinge deformation was also concentrated at this location. The difference in hinge locations between the two specimens was not obvious during the test.

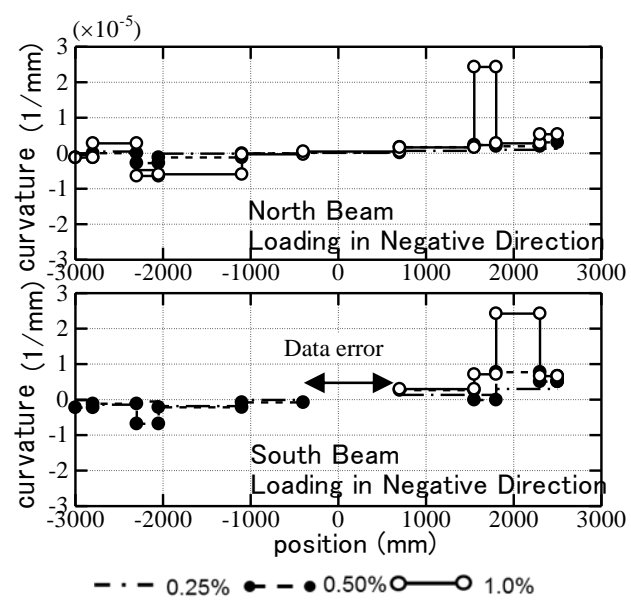

Figure 24: Curvature distribution of the 2nd floor beams in the 2015 full-scale test.

\section{CONCLUSION}

The study shows the outline of two static loading tests performed on a full scale five storey reinforced concrete building. In the 2014 full-scale test, the moment resisting frames consisted of beams and columns with wing walls. The hanging walls, spandrel walls and mullion walls are separated from the main frame by forming gaps. In the 2015 full-scale test, the moment resisting frames consisted of beams with spandrel walls and hanging walls and columns with wing walls. The following conclusions can be drawn from the test results:

- In the 2014 full-scale test, the load displacement response indicated ductile hysteretic behaviour until $2 \%$ drift and the maximum strength of the specimen was 1.84 times of the maximum strength of the moment resisting frame estimated from design calculations.

- In the 2015 full-scale test, the load displacement response indicated the onset of strength deterioration at $0.74 \%$ drift and the maximum strength of the specimen was 3.3 times of the maximum strength of the moment resisting frame estimated from design calculations.

- The 2014 full scale test specimen exhibited a beam sway mechanism, and the 2015 full scale test specimen exhibited a mixed mechanism with column yielding between the $1^{\text {st }}$ to $3^{\text {rd }}$ storeys. Both frames formed obvious beam hinges. The cracking in the beams and slabs restrained the damage to the beam column joint, but the residual crack width of the beams was wider than those of the columns due to either the elongation of the beams or concentration of the concrete cracks.

- The damage of the frames was evaluated from the residual energy capacity. The 2014 test specimens showed minor damage at $0.75 \%$ drift and the 2015 test specimens showed light damage at $0.33 \%$ drift. Those damage grades for beam hinging frame are obviously smaller than the damage grades with the conventional evaluation based on the residual crack width of beams and columns. 


\section{ACKNOWLEDGEMENTS}

This study was carried out by a joint study of the National Technology Development Project of MLIT "Development of function sustaining technologies for buildings used as Disaster Prevention Bases" (2013 2016) and Priority Research Program of BRI Development on Seismic Design Methods for Buildings with Post-Earthquake Functional Use" (2013 2015). The grand design of the test was planned by the Technical WG (Chairman Professor Teshigawara at Nagoya University). The static loading tests were carried out by Structural Engineers of Nishimatsu Construction Co. Ltd., Hazama Ando Corporation, Kumagai Gumi, Sato Kogyo Co. Ltd, Toda Corporation, Fujita Corporation, and Maeda Corporation. The efforts in measuring concrete cracking by Tokyo Institute of technology, Tokyo University of Science and Tohoku University are gratefully acknowledged.

\section{REFERENCES}

1 Building Research Institute and National Institute for Land and Infrastructure Management. (2011). "Summary of the Field Survey and Research on the 2011 off the Pacific Coast of Tohoku Earthquake". Technical Note of National Institute for Land and Infrastructure Management No. 647 and BRI Research Paper No. 150, Japan, 172pp.

2 Ministry of Land, Infrastructure, Transport and Tourism Government Building Department (1996). "A General
Structural Design, Standards and Commentary of the Government Facilities". Japan, 240 pp.

3 Kabeyasawa T, Mukai T, Fukuyama H, Kato H, Suwada H, Teshigawara M and Kusunoki K (2016). "A full scale static loading tests on five story reinforced concrete building utilizing columns with wing walls". Journal of Structural and Construction Engineering, 81(720): 313322.

4 Fukuyama $\mathrm{H}$ et al. (2016). "A full scale static loading tests on five story reinforced concrete building utilizing walls (Part 1 7)". Proceedings of the AIJ Annual Conference, August 4-6, Fukuoka: 313-322 (in Japanese).

5 Okamoto S, Yoshimura M, Kaminosono $\mathrm{T}$ and Isoishi $\mathrm{H}$ (1981). "US-Japan Joint Research a study on a seismic performance of a full-scale 7 story reinforced concrete specimen (Part 4) preliminary static loading test". Proceedings of AIJ Annual Conference, 56: 1269-1270 (in Japanese).

6 National Institute for Land and Infrastructure Management and Building Research Institute (2015). "Guideline of the Structure Related Technical Standard of the Building". Japan, 785 pp (in Japanese).

7 The Japan Building Disaster Prevention Association (2001). "Post Earthquake Damage Evaluation and Restoration Technology Guidance for Seismic Damaged Buildings". Japan, 620 pp (in Japanese). 